\title{
Texture and organic carbon contents do not impact amount of carbon protected in Malagasy soils
}

\author{
Tantely Razafimbelo ${ }^{1}$, Tiphaine Chevallier ${ }^{3}$, Alain Albrecht',3, Lydie Chapuis-Lardy², Fela Nirina Rakotondrasolo²,2, Roger \\ Michellon ${ }^{4,5}$, Lilia Rabeharisoa ${ }^{1}$, Martial Bernoux ${ }^{3 *}$
}

\author{
'Université d'Antananarivo/Laboratoire des Radioisotopes \\ (LRI-SRA), BP 3383, Route d'Andraisoro, 101 - Antananarivo \\ - Madagascar. \\ 2IRD/UMR - Eco\&Sols, BP 434, Ambatoroka, 101 - \\ Antananarivo - Madagascar. \\ ${ }^{3}$ RRD/UMR - Eco\&Sols, Campus SupAgro - Bât. 12, 2 place \\ Viala 34060 - Montpellier - cedex 2 - France. \\ 4Tany sy Fampandrosoana, NGO Land and Development, BP \\ 266, 110 Antsirabe - Madagascar. \\ ${ }^{5}$ CIRAD, Ampandrianomby - BP 853 - Madagascar. \\ *Corresponding author <martial.bernoux@ird.fr> \\ Edited by : Margarita L. Osterrieth
}

\begin{abstract}
Soil organic carbon (SOC) is usually said to be well correlated with soil texture and soil aggregation. These relations generally suggest a physical and physicochemical protection of SOC within soil aggregates and on soil fine particles, respectively. Because there are few experimental evidences of these relations on tropical soils, we tested the relations of soil variables (SOC and soil aggregate contents, and soil texture) with the amount of SOC physically protected in aggregates on a set of 15 Malagasy soils. The soil texture, the SOC and water stable macroaggregate (MA) contents and the amount of SOC physically protected inside aggregates, calculated as the difference of $C$ mineralized by crushed and intact aggregates, were characterized. The relation between these variables was established. SOC content was significantly correlated with soil texture (clay+fine silt fraction) and with soil MA amount while protected SOC content was not correlated with soil MA amount. This lack of correlation might be attributed to the highest importance of physicochemical protection of $\mathrm{SOC}$ which is demonstrated by the positive relation between SOC and clay+fine silt fraction.

Keywords: macroaggregate, tropical soils, soil structure, carbon stabilization
\end{abstract}

Received January 16, 2012

Accepted February 04, 2013

\section{Introduction}

The management and enhancement of soil organic carbon (SOC) is very important for agriculture (fertility) as well as for the environment (carbon sequestration), mainly in tropical regions (Bernoux et al., 2006; Cerri et al., 2007) where development, food security, adaptation and mitigation have to be promoted in synergy (Bernoux et al., 2010). Three main mechanisms of SOC protection in soil exist: (i) biochemical stabilization, (ii) chemical stabilization and (iii) physical protection (Six et al., 2002). Relations between SOC and soil texture have been attributed to a chemical stabilization of SOC by physicochemical adsorption of SOC on soil clay/mineral surface (Feller and Beare, 1997). These relations showed that clayey soils have more potential for SOC storage than sandy soils (Siqueira Neto et al., 2010). Therefore the percentage of clay content, or alternatively clay + silt, is a good predictor of SOC (Nichols et al., 1984). On the other hand, SOC is commonly reported to correlate with soil macroaggregate amounts because SOC enhance macroaggregates formation by its action as a binding agent (Tisdall and Oades, 1982; Metay et al., 2007), and inversely macroaggregates may isolate and protect SOC against microbial attack (Beare et al., 1994).

The protected $\mathrm{C}$ inside macroaggregates is defined as the "physically protected C" pool. Aggregates physically protect SOC by forming physical barriers between microbial enzymes and their substrates, by controlling $\mathrm{O}_{2}$ diffusion, and by influencing food web interactions and consequently microbial turnover (Six et al., 2002).
Several reserachers measured the increase in soil respiration $\left(\Delta \mathrm{CO}_{2}\right)$ when aggregates had been destroyed by soil crushing, and considered the additional carbon mineralized as the pool of SOC physically protected in soil aggregation (e.g. Beare et al., 1994; Chevallier et al., 2004; Metay et al., 2007; Razafimbelo et al., 2008). Since macroaggregates protect SOC from mineralization, macroaggregate amount should correlate with the amount of SOC protected within macroaggregate. However, Pulleman and Marinissen (2004) showed that the amount of SOC protected within larger macroaggregates was lower in a pasture soil which had higher amount of macroaggregates than in a cultivated soil. Therefore, there was probably no unique trend of SOC physical protection and biodegradation schemes because of different features of aggregates.

Most studies characterizing the amount of protected SOC affected by soil management compare tilled and no-tilled systems (Beare et al., 1994; Razafimbelo et al., 2008), or pasture and cultivated lands (Chevallier et al., 2004; Pulleman and Marinissen, 2004) for a given temperate or tropical soil. No studies had examined the relation between the macroaggregate and the physically protected SOC for a range of tropical soils in which soil texture, SOC amount, and macroaggregation level vary. This study aimed to identify among three soil parameters (SOC and macroaggregates contents, and soil texture), (i) which of them better correlates with the physical protection of SOC for 15 contrasted Malagasy soils and (ii) to discuss the main mechanism responsible for SOC accumulation in such soils. 


\section{Materials and Methods}

This study was conducted on 15 soils of Madagascar representing some major tropical soil types used in agriculture and providing a wide range of texture, from sandy to clayey soil (Table 1) as well as organic carbon contents (high and low level) in the soil surface layer (Table 2). Soil samples were collected from various pedoclimatic conditions in Madagascar: in the sub arid Southwest, around the city of Tuléar $\left(23^{\circ} 07^{\prime} \mathrm{S}, 44^{\circ} 13^{\prime}\right.$ $\mathrm{E})$, along the eastern subequatorial coast near Manakara $\left(22^{\circ} 12^{\prime} \mathrm{S}, 47^{\circ} 50^{\prime} \mathrm{E}\right)$, under the altitude tropical climate of the Highlands near Antsirabe (19 $46^{\prime}$ S, $47^{\circ} 06^{\prime}$ E) and under mid-altitude tropical climate near Alaotra lake

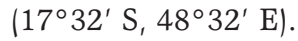

Potentially high and low values of SOC were selected in each site by sampling crop plots of an equivalent soil texture. Three samples were collected per plot at $0-5 \mathrm{~cm}$ depth, and pooled to form a composite sample. Composite samples were air-dried and sieved $(<2 \mathrm{~mm})$. All laboratory analyses were conducted in triplicate. Total soil organic C (g OC $\mathrm{kg}^{-1}$ dry soil) was determined on a forcibly sieved $(<0.2 \mathrm{~mm})$ subsample by dichromate oxidation (Walkley and Black, 1934). Water stable macroaggregate $\left(\mathrm{MA},>0.2 \mathrm{~mm}\right.$ ) fraction $\left(\mathrm{g} \mathrm{MA} \mathrm{kg}^{-1}\right.$ dry soil) was determined using an adaptation of Kemper and Rosenau (1986) method as described in details in Razafimbelo et al. (2008). Mineralizable soil C and the degree of protection from decomposition provided by soil macroaggregates $>0.2 \mathrm{~mm}$ were evaluated during extended laboratory incubations of either intact or crushed soil samples (Chevallier et al., 2004; Razafimbelo et al., 2008).

To break down macroaggregates, soil was crushed to pass a $0.2-\mathrm{mm}$ mesh size. No pre-treatment was performed before incubation as usually in $\mathrm{C}$ physical pro- tection assays (Beare et al., 1994; Gartzia-Bengoetxea et al., 2011). The increase in mineralization rate observed between intact soils (intact aggregates, SOC protected) and crushed soils (aggregates disrupted, SOC not protected and mineralized) was assumed to the SOC which was initially physically protected inside soil aggregates (Beare et al., 1994). Briefly, $10 \mathrm{~g}$ of soil samples were placed into air-tight 1.2-L jars and soil moisture was maintained with deionized water at $80 \%$ of water potential as determined at $-0.01 \mathrm{MPa}$. Carbon dioxide accumulated in the jar was regularly measured during a 28-days incubation period $\left(28{ }^{\circ} \mathrm{C}\right.$ in darkness) using a

Table 2 - Soil organic carbon (SOC), macroaggregates (MA) contents of the topsoils (0-5 cm depth) and SOC protected within macroaggregates after 28 days of incubation. Means and standard deviation in parenthesis $(n=3)$.

\begin{tabular}{|c|c|c|c|c|c|c|}
\hline \multirow{3}{*}{$\begin{array}{l}\text { Code } \\
\text { TA1 }\end{array}$} & \multicolumn{2}{|c|}{ SOC } & \multicolumn{2}{|c|}{ MA } & \multicolumn{2}{|c|}{ Protected SOC } \\
\hline & \multicolumn{4}{|c|}{$\mathrm{g} \mathrm{kg}^{-1}$ soil } & \multicolumn{2}{|c|}{$\mathrm{mg} \mathrm{C}-\mathrm{CO}_{2} \mathrm{~kg}^{-1}$ soil } \\
\hline & 24.1 & $(14.0)$ & 404 & (131) & 62 & $(10)$ \\
\hline TA2 & 12.8 & $(1.6)$ & 305 & $(21)$ & 55 & (14) \\
\hline TS1 & 22.1 & $(4.4)$ & 153 & (30) & 145 & (18) \\
\hline TS2 & 11.6 & $(5.2)$ & 182 & (38) & 62 & (17) \\
\hline TS3 & 23.0 & (8.0) & 143 & (39) & 94 & (56) \\
\hline M1 & 21.3 & $(4.0)$ & 369 & (46) & 111 & (61) \\
\hline M2 & 17.7 & (3.3) & 340 & (27) & 79 & (29) \\
\hline A1 & 34.0 & $(1.2)$ & 522 & (56) & 49 & (117) \\
\hline A2 & 50.2 & $(4.0)$ & 691 & (26) & 198 & (373) \\
\hline A3 & 29.0 & $(4.2)$ & 398 & (12) & 193 & (120) \\
\hline AL1 & 17.2 & (2.8) & 401 & (16) & 86 & (42) \\
\hline AL2 & 14.2 & (4.5) & 344 & (41) & 52 & (32) \\
\hline AL3 & 17.6 & (6.4) & 426 & (74) & 100 & (18) \\
\hline AL4 & 7.3 & $(0.5)$ & 233 & (16) & 13 & (35) \\
\hline AL5 & 10.3 & (2.6) & 222 & (47) & 15 & (79) \\
\hline
\end{tabular}

Table 1 - Collection site description and Clay+Fine silt content (soil texture) of the selected soils.

\begin{tabular}{|c|c|c|c|c|c|}
\hline Sample region & $\begin{array}{l}\text { Average Annual } \\
\text { Precipitation }\end{array}$ & $\begin{array}{l}\text { Average Annual } \\
\text { Temperature }\end{array}$ & Code & Soil type ${ }^{a}$ & Clay + Fine silt ${ }^{b}$ \\
\hline & $\mathrm{mm}$ & ${ }^{\circ} \mathrm{C}$ & & & $\mathrm{g} \mathrm{kg}^{-1}$ soil \\
\hline \multirow[t]{2}{*}{ Tulear-Andranovory } & 600 & 28 & TA1 & Cambisol & 590 \\
\hline & & & TA2 & Cambisol & 590 \\
\hline \multirow[t]{3}{*}{ Tulear-Sakaraha } & 300 & 28 & TS1 & Arenosol & 200 \\
\hline & & & TS2 & Arenosol & 230 \\
\hline & & & TS3 & Arenosol & 125 \\
\hline \multirow[t]{2}{*}{ Manakara } & 2500 & 23 & M1 & Ferralsol & 390 \\
\hline & & & M2 & Ferralsol & 390 \\
\hline \multirow[t]{3}{*}{ Antsirabe } & 1600 & 16 & $\mathrm{~A} 1$ & Ferralsol & 723 \\
\hline & & & $\mathrm{A} 2$ & Ferralsol & 723 \\
\hline & & & A3 & Ferralsol & 539 \\
\hline \multirow[t]{5}{*}{ Alaotra Lake } & 1200 & 20 & AL1 & Ferralsol & 459 \\
\hline & & & AL2 & Ferralsol & 235 \\
\hline & & & AL3 & Fluvisol & 257 \\
\hline & & & AL4 & Fluvisol & 185 \\
\hline & & & AL5 & Fluvisol & 273 \\
\hline
\end{tabular}

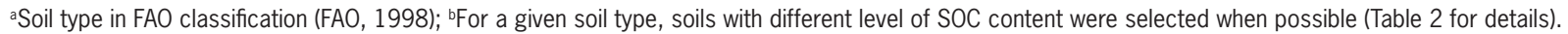


Varian CP4900 Microgas Chromatograph (Varian Chromatography Group, Walnut Creek, CA, USA).

Statistical differences between SOC mineralized in intact and crushed soils were determined with $t$ Student test using XLSTAT software for windows. Kendall's correlation coefficients $(\tau)$ were calculated to evaluate the significance of correlations between soil variables. Kendall test was used as the normal distribution of the data was not achieved even using usual transformations.

\section{Results and Discussion}

In this study, soil texture was expressed as the soil content of soil fine particles, i.e. the clay + fine silt fraction, the soil particles $<20 \mu \mathrm{m}$. The sample set covered a wide range of clay + fine silt, from 125 to $723 \mathrm{~g} \mathrm{~kg}^{-1}$ soil, and a wide range of soil organic $\mathrm{C}$ contents, from 7 to $50 \mathrm{~g} \mathrm{OC} \mathrm{kg}^{-1}$ soil (Tables 1 and 2). SOC content and soil texture were positively correlated $(\tau=0.39, p$ $=0.045$ ), with the lower $\mathrm{C}$ concentrations observed in sandy soils and the highest in clayey soils (Figure 1A). Such a positive relation was highlighted for tropical soils (Feller and Beare, 1997) and attributed to sorption processes of colloidal-soluble SOC on clay surface (Zinn et al., 2007) and/or in SOC protection by macroaggregates in fine-textured soil (Feller and Beare, 1997).

The sample set also covered a wide range of soil macroaggregate $>0.2 \mathrm{~mm}$ contents, from 143 to $691 \mathrm{~g}$ MA kg-1 soil (Table 2). Macroaggregates and SOC contents were also positively correlated $(\tau=0.41, p=$ 0.036) (Figure 1B). This can be interpreted in two ways: (i) SOC binds soil particles to form soil macroaggregates (Tisdall and Oades, 1982) and (ii) soil aggregation physically protects SOC against mineralization (Beare et al., 1994). The occlusion of particulate organic matter inside macroaggregates and the diffusion and deposition of organic compounds inside aggregate micropores which were too small for microbes (Tisdall and Oades, 1982; McCarthy et al., 2008) were assumed to be the processes responsible for the physical protection of SOC against microbial attack.
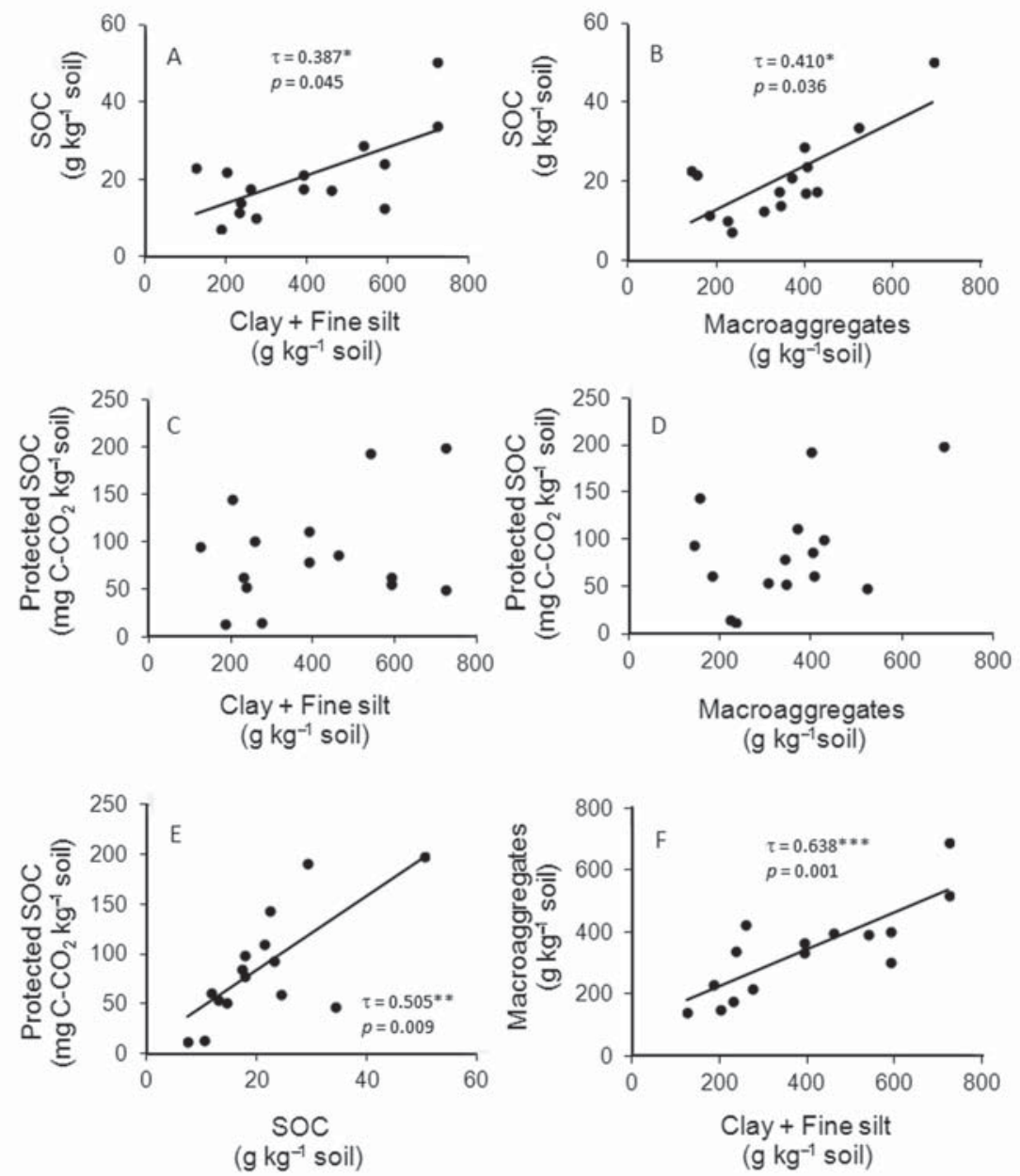

Figure 1 - Linear relationships between soil texture, soil organic carbon (SOC), macroaggregates, mineralized C and protected SOC in 15 Malagasy soils. Probability levels for the relationships when appropriate: ${ }^{*} p<0.05 ;{ }^{* *} p<0.01 ;{ }^{* *} p<0.001$ (Kendall test). 
Our mineralization assay demonstrated such a physical protection of SOC. The mineralized SOC ranged from 377 to $1510 \mathrm{mg}$ C-CO2 $\mathrm{kg}^{-1}$ soil for intact soils, and from 431 to $1708 \mathrm{mg} \mathrm{C}-\mathrm{CO} 2 \mathrm{~kg}^{-1}$ soil for crushed soils, respectively. The increase (Student $t$ test, $p<0.05$ ) of mineralized SOC when the soil was crushed $1+13$ to $+198 \mathrm{mg}$ C-CO2 $\mathrm{kg}^{-1}$ soil) highlighted the presence of an amount of SOC physically protected inside macroaggregates (Figure 2). This SOC physically protected represented an average of $10 \%$ of total mineralized SOC (varying from 1 to $25 \%$ of total mineralized SOC) and $4.1 \%$ of total SOC (varying from 1.5 to $7 \%$ of total SOC) (Table 2). This rate of SOC physically protected are much higher than those found by Chevallier et al., (2004) or Pulleman and Marinissen (2004), which are 1 to 2.5 and 0.5 to $1.4 \%$ of total SOC, respectively. However, neither soil texture (Figure 1C) nor macroaggregate content (Figure 1D) was correlated with protected SOC while a positive relationship was found between macroaggregates and SOC contents (Figure 1B). However, even if a positive relationship was found between macroaggregates and SOC contents (Figure 1B) and between SOC content and protected SOC (Figure 1E), no correlation was found between the amount of protected SOC inside macroaggregates and the amount of macroaggregates.

Macroaggregates were not always considered as efficient OM protecting sites against mineralization, as underlined by Pulleman and Marinissen (2004). These authors found that macroaggregates protected SOC in arable fields when aggregation was dominated by large and dense physicogenic aggregates (aggregates formed by physical processes, few biopores), but did not protect SOC in a pasture soil when aggregation was dominated by porous and biogenic aggregates (aggregates formed by biological processes, many biopores). The larger pore distribution inside such macroaggregates

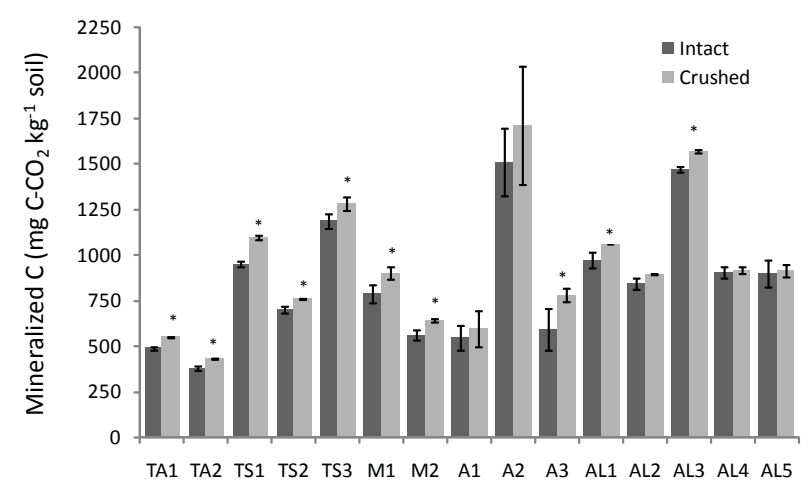

* Significantdifferencesbetween Crushedand Intactsoils (Studentttest, $p<0.05$ ). Figure 2 - Soil organic carbon mineralized during the 28-d incubation of intact and crushed soils (mean and standard deviation, $n=3$ ). facilitated OM mineralization by microbes (Pulleman and Marinissen, 2004). In our study, eight samples were collected in no-tillage systems and two in fallow systems. These systems are quite rich in macrofauna activity (Blanchart et al., 2007), therefore we could have more biogenic than physicogenic aggregates in the studied soils.

The absence of relationship between the amount of macroaggregates and the amount of protected SOC inside macroaggregate could not exclude the total absence of physical protection of SOC inside soil structure. The physical protection of SOC inside aggregates smaller than $0.2 \mathrm{~mm}$ has not been tested in that study. The protection of SOC inside microaggregates, often described in literature (Six et al., 2004) is possible.

However, in tropical soils which contains oxides the direct linkage between SOC accumulation and aggregates amount is not evident (Zotarelli et al., 2005). Indeed in these soils, physical protection within aggregates is not the main mechanism for OM stabilization as in temperate soils (Tisdall and Oades, 1982; Barthès et al., 2008). Barthes et al. (2008) reported that the main factors which influence SOM accumulation and macroaggregate stabilization in 18 tropical soils was the soil content of Al-containing crystalline sesquioxides.

Recent studies using some soil samples of our study showed effectively high contents of $\mathrm{Al}$ oxides, from 4 to 16 $\mathrm{g} \mathrm{Al}_{\mathrm{CBD}} \mathrm{kg}^{-1}$ soil and from 2 to $11 \mathrm{~g} \mathrm{Al}_{\mathrm{Ox}} \mathrm{kg}^{-1}$ soil for free, i.e. $\mathrm{Al}$ oxides extractable in citrate-bicarbonate-dithionite $\left(\mathrm{Al}_{\mathrm{CBD}}\right)$ and amorphous forms of $\mathrm{Al}$, i.e. extractable in ammonium oxalate $\left(\mathrm{Al}_{\mathrm{Ox}}\right)$, respectively, and high contents of $\mathrm{Fe}$ oxides, from 38 to $46 \mathrm{~g} \mathrm{Fe}_{\mathrm{CBD}} \mathrm{kg}^{-1}$ soil and from 0.48 to 3.48 $\mathrm{g} \mathrm{Fe}_{\mathrm{OX}} \mathrm{kg}^{-1}$ soil for free, i.e. Fe oxides extractable in citratebicarbonate-dithionite $\left(\mathrm{Fe}_{\mathrm{CBD}}\right)$ and amorphous forms of $\mathrm{Fe}$, i.e. extractable in ammonium oxalate $\left(\mathrm{Fe}_{\mathrm{OX}}\right)$, respectively (e.g. Chapuis-Lardy et al., 2009). As soil Al or Fe oxides are generally associated with clay + fine silt fraction contents (Zinn et al., 2007), our results showed a correlation of clay + fine silt fraction with SOC (Figure 1A) and with macroaggregates (Figure $1 \mathrm{~F}$ ). The formation of organo-mineral complexes which protect SOC from biodegradation (Wiseman and Püttemann, 2005; Mikutta et al., 2006) and the adsorption of SOC on the high specific surface area resulting from Al- Fe substitution (Barthes et al., 2008) might explained this positive relationship between clay + fine silt contents and SOC content (Figure 1A). Therefore, these results confirm SOC physicochemical stabilization for SOC accumulation mechanisms in such soils.

\section{Acknowledgements}

This research was co-financed by the French Ministry of Foreign Affairs (MAEE) through the AIRES-Sud project $n^{\circ} 7149$, the AFD (Agence Française pour le Développement) and the Fond Français pour l'Environnement Mondial (FFEM) through the RIME-PAMPA project $n^{\circ}$ CZZ 3076 PAMPA, and the International Foundation for Science (IFS). 


\section{References}

Barthès, B.G.; Kouakoua, E.; Larré-Larrouy, M.C.; Razafimbelo, T.M.; De Luca, E.F.; Azontonde, A.; Neves, C.S.V.J.; De Freitas, P.L.; Feller, C.L. 2008. Texture and sesquioxide effects on water-stable aggregates and organic matter in some tropical soils. Geoderma 143: 14-25.

Beare, M.H.; Cabrera, M.L.; Hendrix, P.F.; Coleman, D.C. 1994. Aggregate-protected and unprotected organic matter pools in conventional- and no-tillage soils. Soil Science Society of America Journal 58: 787-795.

Bernoux, M.; Branca, G.; Carro, A.; Lipper, L.; Smith, G.; Bockel, L. 2010. Ex-ante greenhouse gas balance of agriculture and forestry development programs. Scientia Agricola 67: 31-40.

Bernoux, M.; Cerri, C.C.; Cerri, C.E.P.; Siqueira Neto, M.; Metay, A.; Perrin, A.S.; Scopel, E.; Razafimbelo, T.; Blavet, D.; Piccolo, M.C.; Pavei, M.; Milne, E. 2006. Cropping systems, carbon sequestration and erosion in Brazil, a review. Agronomy for Sustainable Development 26: 1-8.

Blanchart, E.; Bernoux, M.; Sarda, X.; Siqueira Neto, M.; Cerri, C.C.; Piccolo, M.C.; Douzet, J.M.; Scopel, E.; Feller, C. 2007. Effect of direct seeding mulch-based systems on soil carbon storage and macrofauna in Central Brazil: Agriculturae Conspectus Scientificus 72: 81-87.

Cerri, C.E.P.; Sparovek, G.; Bernoux, M.; Easterling, W.E.; Melillo, J.M.; Cerri, C.C. 2007. Tropical agriculture and global warming: impacts and mitigation options. Scientia Agricola 64: 83-89.

Chapuis-Lardy, L.; Metay, A.; Martinet, M.; Rabenarivo, M.; Toucet, J.; Douzet, J.M.; Razafimbelo, T.; Rabeharisoa, L.; Rakotoarisoa, J. 2009. Nitrous oxide fluxes from Malagasy agricultural soils. Geoderma 148: 421-427.

Chevallier, T.; Blanchart, E.; Albrecht, A.; Feller, C. 2004. The physical protection of soil organic carbon in aggregates: a mechanism of carbon storage in a Vertisol under pasture and market gardening (Martinique, West Indies). Agriculture, Ecosystem and Environment 103: 375-387.

Food and Agriculture Organization [FAO]. 1998. World Reference Base for Soil Resources. FAO-ISRIC-ISSS, Rome, Italy.

Feller, C.; Beare, M.H. 1997. Physical control of soil organic matter dynamics in the Tropics. Geoderma 79: 69-116.

Gartzia-Bengoetxea, N.; Arbestain, M.C.; Mandiola, E.; Martínez De Arano, I. 2011. Physical protection of soil organic matter following mechanized forest operations in Pinus radiata D. Don plantations. Soil Biology and Biochemistry 43: 141-149.

Kemper, W.D.; Rosenau, R.C. 1986. Aggregate stability and size distribution. p. 425-442. In: Klute, A., ed. Methods of soil analysis. Part 1. Physical and mineralogical methods. ASASSSA-CSSA, Madison, WI, USA. (Agronomy Monographs).

McCarthy, J.F.; Ilavsky, J.; Jastrow, J.D.; Mayer, L.M.; Perfect, E.; Zhuang, J. 2008. Protection of organic carbon in soil microaggregates via restructuring of aggregate porosity and filling of pores with accumulating organic matter. Geochimica et Cosmochimica Acta 72: 4725-4744.
Metay, A.; Alves Moreira, J.A.; Bernoux, M.; Boyer, T.; Douzet J.M.; Feigl, B.; Feller, C.; Maraux, F.; Oliver, R.; Scopel, E. 2007. Storage and forms of organic carbon in a no-tillage under cover crops system on clayey Oxisol in dryland rice production (Cerrados, Brazil). Soil \& Tillage Research 94: 122-132.

Mikutta, R.; Kleber, M.; Torn, M.S.; Jahn, R. 2006. Stabilization of soil organic matter: association with minerals or chemical recalcitrance? Biogeochemistry 77: 25-56.

Nichols, J.D. 1984. Relation of organic carbon to soil properties and climate in the Southern Great Plains. Soil Science Society of America Journal 48: 1382-1384.

Pulleman, M.M.; Marinissen, J.C.Y. 2004. Physical protection of mineralizable $\mathrm{C}$ in aggregates from long-term pasture and arable soil. Geoderma 120: 273-282.

Razafimbelo, T.; Albrecht, A.; Oliver, R.; Chevallier, T.; ChapuisLardy, L.; Feller, C. 2008. Aggregate associated-C and physical protection in a tropical clayey soil under Malagasy conventional and no-tillage systems. Soil and Tillage Research 98: 140-149.

Siqueira Neto, M.; Scopel, E.; Corbeels, M.; Nunes Cardoso, A.; Douzet, J.M.; Feller, C.; Piccolo, M.C.; Cerri, C.C.; Bernoux, M. 2010. Soil carbon stocks under no-tillage mulch-based cropping systems in the Brazilian Cerrado: an on-farm synchronic assessment. Soil \& Tillage Research 110: 187-195.

Six, J.; Bossuyt, H.; Degryze, S.; Denef, K. 2004. A history of research on the link between (micro) aggregates, soil biota, and soil organic matter dynamics. Soil and Tillage Research 79: 7-31.

Six, J.; Conant, T.; Paul, A.; Paustian, K. 2002. Stabilization mechanisms of soil organic matter: implications for C-saturation of soils. Plant and Soil 241: 155-176.

Tisdall, J.M.; Oades, J.M. 1982. Organic matter and water-stable aggregates in soils. Journal of Soil Science 33: 141-163.

Walkley, A.; Black, I.A. 1934. An examination of the Degtjareff method for determining soil organic matter and a proposed modification of the chromic acid titration method. Soil Science 37: 29-38.

Wiseman, C.L.S.; Püttmann, W. 2005. Soil organic carbon and its sorptive preservation in central Germany. European Journal of Soil Science 56: 65-76.

Zinn, Y.L.; Lal, R.; Bigham, J.M.; Resck, D.V.S. 2007. Edaphic controls on soil organic carbon retention in the Brazilian Cerrado: texture and mineralogy. Soil Science Society of America Journal 71: 1204-1214.

Zotarelli, L.; Alves, B.J.R.; Urquiaga, S.; Torres, E.; dos Santos, H.P; Paustian, K.; Boddey, R.M.; Six, J. 2005. Impact of tillage and crop rotation on aggregate-associated carbon in two oxisols. Soil Science Society of America Journal 69: 482-491. 